\title{
A respiratory survey in a black Johannesburg workforce
}

\author{
Khathatso E Mokoetle, Magda de Beer, Margaret R Becklake
}

\begin{abstract}
Background - The burden and determinants of airway disease in the population of southern Africa, which is currently undergoing rapid, often uncontrolled, urbanisation and industrialisation, are unknown. Previous surveys have focused on specific occupational groups and few have included women. This paper describes the respiratory status in a $30 \%$ probability sample of 206 men and 203 women drawn from an urban black Johannesburg workforce of almost 1500, all working for an educational institution.

Methods - Subjects answered a respiratory questionnaire and performed spirometric tests. Symptom rates and age and height standardised forced vital capacity (FVC), forced expiratory volume in one second $\left(F E V_{1}\right), F E V_{1} / F V C \%$, and forced expiratory flow $\left(F_{E F} F_{25-75}\right)$ were analysed by gender in relation to smoking, past work exposures, past and recent respiratory conditions, and socioeconomic indicators.
\end{abstract}

Results - Symptom prevalence was high, bronchitic symptoms in men being related to smoking and previous occupational exposure, and in women to smoking despite the low intensity of their habit. Phlegm and wheezing were related to childhood respiratory illness in both men and women. FVC and FEV , based on all subjects including smokers, were higher than previously reported for black residents of southern Africa. FVC was also positively related to education and job category. Higher values for ever smokers than for never smokers suggested health selection into the habit, while significant negative smoking effects were seen only on $\mathrm{FEV}_{1} / \mathrm{FVC} \%$ and only in women.

Conclusions - Despite the high prevalence of symptoms - some smoking related - in this urban workforce, lung function levels were higher than previously reported in African blacks, and may reflect improving socioeconomic conditions.

(Thorax 1994;49:340-346)

Respiratory surveys, community or workforce based, are used to establish the burden and determinants of respiratory diseases or conditions in populations. Commonly used measurement tools are the respiratory symp- tom questionnaire, lung function tests and, for certain diseases, chest radiography..$^{1-5}$ To date, most surveys carried out in black southern African adult populations $s^{6-20}$ have focused on occupational groups with exposures to identified airborne pollutants such as mine dust, ${ }^{9121618}$ grain, ${ }^{1120}$ cotton, ${ }^{14}$ and asbestos dust. ${ }^{10}$ Only two studies included women, ${ }^{68}$ and there have been few descriptions of both symptoms and lung function in black South Africans in relation to the major recognised determinants of respiratory health, namely age, gender, and smoking. In a joint World Health Organisation (WHO)/International Union Against Tuberculosis and Lung Disease (IUATLD) consultation on chronic airways disease ${ }^{3}$ Chaulet pointed out that, in 1987, of approximately 560 million inhabitants on the African continent, 100 million were in southern Africa including south tropical Africa and the Indian Ocean islands. ${ }^{4}$ This population is young, over $50 \%$ being under the age of 20 , and is experiencing rapid and often uncontrolled urbanisation as well as industrialisation. Non-specific airways diseases constitute an important public health problem because of their frequency as well as their medical and social cost.

The primary objective of the present study was to contribute to the better documentation of the respiratory health status of the black men and women of southern Africa. A secondary objective was to gather information pertinent to the development of southern African based reference values for lung function for use in the clinical interpretation of pulmonary function tests. ${ }^{21-23}$ While such values are available both for black ${ }^{24-28}$ and white subjects ${ }^{28-32}$ based on studies carried out in non-smoking populations resident in other parts of the world, current recommendations are that they should be based on appropriately selected local populations. ${ }^{23}$ In the rapidly urbanising societies of southern Africa the influence of changing socioeconomic status on lung function may also be considerable. ${ }^{33} 34$

\section{Methods}

POPULATION

The source population for the present study comprised all 1480 black men and women employed at the University of the Witwatersrand in 1986, a workforce not exposed to specific industrial hazards but covering a wide range of ages, education, and jobs. University administration staff lists of black employees, stratified by gender, were used as a sampling frame. A $30 \%$ computer generated random sample yielded the names of 222 men and 222 
women. Because of the small number of black academic staff all 25 of them were included in the study sample, yielding a total study sample of 469 subjects. Permission to perform the study at the university and to collect data during working hours was granted by the University with the cooperation of the Black University Workers' Association. Participation was voluntary. The protocol was approved by the University ethics committee.

\section{MEASUREMENTS}

Respiratory health status was evaluated from questionnaire information and lung function measurements. Two trained interviewers administered a modified version of the American Thoracic Society respiratory questionnaire ${ }^{1}$ currently in use at the National Centre for Occupational Health in Johannesburg. ${ }^{5}$ Additional questions dealt with education and position(s) held in the present job structure. Questions from an English version of the questionnaire were either read out in English or translated by the interviewers into Sotho, Zulu, Tswana, or Xhosa, whichever the interviewee preferred. ${ }^{5}$ Questionnaire data were processed using Dbase III computer software. Standing height was measured with the subject standing upright without shoes, and sitting height with the subject seated upright on a bench. Weight was measured in kilograms without shoes, coats, or jackets. The body mass index (weight/ $/$ height $^{2}$ ) was considered to indicate obesity when it exceeded 25 in men and 26 in women. ${ }^{7}$

Spirometric lung function tests were performed using a Model 5 Vitalograph linked to a computer for direct recording. The machine was calibrated for volume every morning and afternoon using a five litre syringe. Subjects performed the tests standing without noseclips; the test procedure followed and the criteria for acceptability were those recommended by the American Thoracic Society. ${ }^{2}$ Full instructions were given on how to do the test, and most participants had the opportunity of watching others perform the test while waiting. A minimum of three acceptable tracings and a maximum of five were obtained from each participant. Barometric and temperature readings were taken throughout the study period. The spirometric values analysed were forced vital capacity (FVC), forced expiratory volume in one second $\left(\mathrm{FEV}_{1}\right), \mathrm{FEV}_{1} /$ $\mathrm{FVC} \%$, and forced expiratory flow $25 \%-75 \%$ $\left(\mathrm{FEF}_{25-75}\right)$. Analysis was based on the best FVC and $\mathrm{FEV}_{1}$ measurements extracted from all the trials recorded, while $\mathrm{FEF}_{25-75}$ was taken from the trial with the maximum sum of FVC and $\mathrm{FEV}_{1}{ }^{2}$

\section{ANALYSIS}

Data were analysed using the statistical analysis system (SAS). Results for men and women were analysed separately. Means and standard deviations were calculated for continuous data, and percentages for categorical data. Because of the small number of ex- smokers, these were combined with current smokers as "ever smokers" for analysis. Packs per year were calculated by multiplying the number of cigarettes smoked per day by 365 and dividing by 20 , the average pack size. Two socioeconomic indicators based on job title and education level achieved were derived for each subject as follows. Jobs were classified as unskilled and semi-skilled/professional, according to a widely used South African job classification system, ${ }^{35}$ taking into account that used at the University. Educational achievement was classified into three categories: none to grade 4 , grades 5 to 9 , and grade 10 (school leaving certificate) and above.

The prevalence of cough and phlegm was derived from a "yes" response to either of the following two questions: "do you usually cough (or bring up phlegm) first thing in the morning", or "during the day or at night?" Prevalence of breathlessness was derived from a "yes" response to any of the following questions on breathlessness: "when hurrying or walking up a slight hill"; "when walking with people of own age on level ground"; and having "to stop for breath when walking at own pace on level ground." The prevalence of "wheeze" was derived from a "yes" answer to the question "does your chest ever sound wheezy or whistling?" The presence of any of the respiratory conditions listed was based on a "yes" answer to the question "have you ever had any of the following conditions", and the conditions were then listed by name. Logistic regression analyses (SAS) were used to identify the determinants of respiratory symptoms. A backward selection procedure was employed. Odds ratios and $95 \%$ confidence intervals were calculated for factors significant at the $5 \%$ level. Explanatory variables included in the analysis were age, smoking (ever/ never), reported past and recent respiratory illnesses, previous dust exposure, educational achievement (three categories), and job category (semi-skilled/skilled and/or professional).

Mean lung function values, standardised for height, were calculated for men and women in four age groups $(20-34,35-44,45-54,55+$ years) and two smoking (never/ever) categories. Multiple regression analysis (GLM) was used to assess the effects of all the explanatory variables listed above for symptoms on lung function level, and stepwise regression analysis was used to identify significant determinants. Estimates of $\beta$ coefficients and $R^{2}$ were also computed for the following models to enable comparison with published data: (1) lung function $=\mathrm{f}$ (age, standing height); (2) lung function $=\mathrm{f}$ (age, sitting height).

\section{Results}

Response rates were $92 \cdot 1 \%$ (218 men, 214 women) for the questionnaire and $87 \cdot 2 \%$ (206 men, 203 women) for both questionnaire and lung function tests. Of the 37 individuals who completed neither, six were out on assignments and one was on sabbatical leave. There were 13 refusals and, for 17 , the reasons for non-participation were unknown. 
Table 1 Characteristics of study subjects

\begin{tabular}{|c|c|c|c|c|}
\hline & \multicolumn{2}{|c|}{$\operatorname{Men}(n=206)$} & \multicolumn{2}{|c|}{ Women $(n=203)$} \\
\hline & $n$ & $\%$ & $n$ & $\%$ \\
\hline $\begin{array}{l}\text { Language of interview } \\
\text { Sotho } \\
\text { Zulu } \\
\text { Tswana } \\
\text { Venda } \\
\text { Xhosa } \\
\text { Other* }\end{array}$ & $\begin{array}{r}51 \\
44 \\
42 \\
34 \\
9 \\
26\end{array}$ & $\begin{array}{r}24 \cdot 7 \\
21 \cdot 3 \\
20 \cdot 4 \\
16 \cdot 5 \\
4 \cdot 5 \\
12 \cdot 6\end{array}$ & $\begin{array}{r}42 \\
55 \\
65 \\
8 \\
25 \\
8\end{array}$ & $\begin{array}{r}20 \cdot 7 \\
27 \cdot 1 \\
32 \cdot 0 \\
3 \cdot 0 \\
12 \cdot 4 \\
3 \cdot 9\end{array}$ \\
\hline $\begin{array}{l}\text { Childhood residence } \\
\text { Urban } \\
\text { Rural }\end{array}$ & $\begin{array}{l}84 \\
122\end{array}$ & $\begin{array}{l}40 \cdot 7 \\
59 \cdot 3\end{array}$ & $\begin{array}{l}146 \\
57\end{array}$ & $\begin{array}{l}71 \cdot 9 \\
28 \cdot 1\end{array}$ \\
\hline $\begin{array}{l}\text { Education completed } \\
\text { None to grade } 4 \\
\text { Grades } 5-9 \\
\text { Grade } 10 \text { and above }{ }^{\dagger}\end{array}$ & $\begin{array}{l}88 \\
77 \\
41\end{array}$ & $\begin{array}{l}42 \cdot 7 \\
37 \cdot 3 \\
20 \cdot 0\end{array}$ & $\begin{array}{l}49 \\
117 \\
37\end{array}$ & $\begin{array}{l}24 \cdot 1 \\
57 \cdot 6 \\
18 \cdot 3\end{array}$ \\
\hline $\begin{array}{l}\text { Current job } \\
\text { Semiskilled } \\
\text { Skilled } \\
\text { Professional }\end{array}$ & $\begin{array}{l}68 \\
124 \\
14\end{array}$ & $\begin{array}{r}33 \cdot 0 \\
60 \cdot 2 \\
6 \cdot 8\end{array}$ & $\begin{array}{l}57 \\
138 \\
8\end{array}$ & $\begin{array}{l}28.0 \\
67 \cdot 9 \\
16 \cdot 1\end{array}$ \\
\hline $\begin{array}{c}\text { Smoking } \\
\text { Never } \\
\text { Ever }\end{array}$ & $\begin{array}{l}65 \\
141\end{array}$ & $\begin{array}{l}31 \cdot 6 \\
68 \cdot 4\end{array}$ & $\begin{array}{l}174 \\
29\end{array}$ & $\begin{array}{l}85 \cdot 7 \\
14 \cdot 3\end{array}$ \\
\hline
\end{tabular}

* Includes Tsonga, Ndebele, Pedi.

+ Grade 10 is the matriculation (school leaving) class.

Table 2 Prevalence (\%) of reported respiratory symptoms and conditions

\begin{tabular}{|c|c|c|c|c|c|}
\hline & \multirow{2}{*}{$\begin{array}{l}\text { Smoking } \\
\text { status }\end{array}$} & \multicolumn{2}{|c|}{$\operatorname{Men}(n=206)$} & \multicolumn{2}{|c|}{ Women $(n=203)$} \\
\hline & & $n$ & $\%$ & $n$ & $\%$ \\
\hline \multicolumn{6}{|l|}{ Symptomst } \\
\hline \multirow{2}{*}{ Usual cough } & Never & 11 & 16.9 & 38 & 21.8 \\
\hline & Ever & 52 & $36 \cdot 8^{*}$ & 15 & $51 \cdot 7^{*}$ \\
\hline \multirow[t]{2}{*}{ Usual phlegm } & Never & 5 & $7 \cdot 7$ & 29 & $16 \cdot 6$ \\
\hline & Ever & 36 & $25 \cdot 5^{*}$ & 6 & $20 \cdot 6$ \\
\hline \multirow[t]{2}{*}{ Ever wheeze } & Never & 7 & $10 \cdot 7$ & 35 & $20 \cdot 1$ \\
\hline & Ever & 20 & $14 \cdot 2$ & 9 & 31.0 \\
\hline \multirow{2}{*}{ Short of breath } & Never & 13 & $20 \cdot 0$ & 94 & $54 \cdot 0$ \\
\hline & Ever & 40 & $28 \cdot 4$ & 21 & $72 \cdot 4^{*}$ \\
\hline \multicolumn{6}{|l|}{ Conditions $\ddagger$} \\
\hline \multirow[t]{2}{*}{ Chest illness before 16} & Never & 1 & 1.5 & 18 & $10 \cdot 3$ \\
\hline & Ever & 12 & $8 \cdot 5$ & 5 & $17 \cdot 2^{*}$ \\
\hline \multirow[t]{2}{*}{ Measles } & Never & 23 & $35 \cdot 3$ & 72 & $41 \cdot \overline{4}$ \\
\hline & Ever & 39 & $27 \cdot 6$ & 14 & $48 \cdot 2$ \\
\hline \multirow[t]{2}{*}{ Chest injury } & Never & 1 & 1.5 & 5 & $3 \cdot 2$ \\
\hline & Ever & 13 & $9 \cdot 2^{*}$ & 2 & $6 \cdot 8$ \\
\hline \multirow[t]{2}{*}{ Bronchitis } & Never & 8 & $12 \cdot 3$ & 41 & $23 \cdot 6$ \\
\hline & Ever & 31 & 21.9 & 2 & 6.8 \\
\hline \multirow{2}{*}{ Bronchial asthma } & Never & 1 & 1.5 & 7 & $4 \cdot 0$ \\
\hline & Ever & 4 & $2 \cdot 8^{*}$ & 0 & 0 \\
\hline \multirow{2}{*}{ Flu in past month } & Never & 16 & $24 \cdot 6$ & 62 & $35 \cdot 8$ \\
\hline & Ever & 49 & $34 \cdot 7$ & 15 & 51.7 \\
\hline
\end{tabular}

For men, the numbers of never smokers were 65 , and ever smokers 141 ; for women these numbers were 174 and 29 (table 1 ).

* Significantly different from non-smokers of the same gender in univariate analyses.

† Based on "yes" answers to certain symptom questions (see text).

+ Based on a "yes" answer to the questions: "have you ever had or do you have any of the following conditions?" (see text).

Table 3 Determinants of respiratory symptoms expressed as odds ratios with confidence intervals

\begin{tabular}{|c|c|c|c|}
\hline Symptom & Determinant & Men & Women \\
\hline Usual cough & $\begin{array}{l}\text { Smoking } \\
\text { Past dusty work } \\
\text { Flu in past month } \\
\text { Recent chest illness } \\
\text { Measles }\end{array}$ & $\begin{array}{l}2.4(1.1 \text { to } 5 \cdot 3) \\
2.6(1.3 \text { to } 5 \cdot 5) \\
2 \cdot 2(1.1 \text { to } 4 \cdot 4) \\
5 \cdot 1(1.7 \text { to } 15 \cdot 1) \\
0.3(0.1 \text { to } 0.9)\end{array}$ & $\begin{array}{l}5 \cdot 3(2 \cdot 3 \text { to } 11 \cdot 7) \\
\text { NS } \\
\text { NS } \\
2 \cdot 8(1 \cdot 3 \text { to } 5 \cdot 8) \\
\text { NS }\end{array}$ \\
\hline Usual phlegm & $\begin{array}{l}\text { Smoking } \\
\text { Past dusty work } \\
\text { Recent chest illness } \\
\text { Past chest illness } \\
\text { Chest illness before } 16 \\
\text { Measles } \\
\text { Job category } \\
\text { Education }\end{array}$ & $\begin{array}{l}2.9(1.1 \text { to } 8.2) \\
2.9(1.3 \text { to } 3.8) \\
5.2(1.5 \text { to } 17.3) \\
2.7(1.2 \text { to } 6.4) \\
\text { NS } \\
0.3(0.1 \text { to } 0.9) \\
0.3(0.2 \text { to } 0.9) \\
0.4(0.1 \text { to } 0.9)\end{array}$ & $\begin{array}{l}\text { NS } \\
\text { NS } \\
\text { NS } \\
\text { NS } \\
3 \cdot 0(1 \cdot 2 \text { to } 7 \cdot 7) \\
\text { NS } \\
\text { NS } \\
\text { NS }\end{array}$ \\
\hline Ever wheeze & $\begin{array}{l}\text { Past chest illness } \\
\text { Chest illness before } 16\end{array}$ & $\begin{array}{l}6 \cdot 2(2 \cdot 3 \text { to } 16 \cdot 8) \\
7 \cdot 4(2 \cdot 1 \text { to } 25 \cdot 6)\end{array}$ & $\begin{array}{l}2.9(1.2 \text { to } 6.8) \\
2.8(1.1 \text { to } 1.9)\end{array}$ \\
\hline Short of breath & $\begin{array}{l}\text { Flu in past month } \\
\text { Recent chest illness } \\
\text { Past chest illness } \\
\text { Job category } \\
\text { Education }\end{array}$ & $\begin{array}{l}2 \cdot 2(1 \cdot 1 \text { to } 4 \cdot 2) \\
6 \cdot 8(2 \cdot 4 \text { to } 19 \cdot 3) \\
\text { NS } \\
\text { NS } \\
\text { NS }\end{array}$ & $\begin{array}{l}2.1(1.4 \text { to } 3.9) \\
\text { NS } \\
2.5(1.4 \text { to } 4.6) \\
3.5(1.6 \text { to } 7.7) \\
4.2(1.6 \text { to } 7.7)\end{array}$ \\
\hline
\end{tabular}

The table lists only the significant $(\mathrm{p} \leq 0.05)$ odds ratios derived from models containing all the potential determinants (see text) and yielded by logistic regression analyses carried out separately in the data for men and women. For smoking and past dusty work the comparisons were ever never smoked; for all respiratory conditions reported $v$ not; for job category skilled/professional semiskilled; for education grades 5-9 $v$ grades $0-4$ (usual phlegm) and grades $10+v$ grades $0-4$ (short of breath).
The average ages for men and women were similar, 42 years and 41 years respectively. Social, smoking, and other exposure characteristics of the study population are shown in table 1. The major ethnic groups in this workforce (as reflected by language of interview) were Sotho, Zulu, and Tswana, with Venda being the next most frequently represented group in men, and Xhosa in women. The majority of men $(59.3 \%)$ were born and spent their childhood in rural areas, the majority of women $(71.9 \%)$ in urban areas. This probably explains why the educational level achieved exceeded grade 4 for more women than men. Although $68 \%$ of men and $14 \%$ of women were current smokers, only 25 men and two women smoked more than 15 cigarettes per day. The men smoked an average of 30.9 packs per year, the equivalent of approximately 13 cigarettes per week, while the women smoked an average of 17.9 packs per year, the equivalent of approximately seven cigarettes per week.

Prevalences of respiratory symptoms and reported illnesses are shown in table 2 . In both men and women the prevalences of cough, phlegm production, wheeze, and shortness of breath were higher in ever smokers than in never smokers. However, the differences were only significant for cough and phlegm in men, and for cough and shortness of breath in women. Shortness of breath was also significantly more frequently reported in women than in men, possibly related to their body mass index which, on average, fell into the obese range for all age groups. ${ }^{7}$ When the definition of shortness of breath was limited to that experienced "when walking with other people of your own age on level ground" and "stopping for breath when walking at your own pace on level ground", the overall prevalence of this symptom was less than $2 \%$ in both men and women. Generally past chest illnesses were reported by a higher proportion of ever smokers than never smokers, and in more women than men.

Table 3 shows the determinants of respiratory symptoms in men and women. Smoking increased the risk of cough and phlegm in men, and of cough in women. Although women were lighter smokers their risk of coughing if they smoked was more than double that of men. Previous exposure to dust at work also increased the risk of cough and phlegm production in men, but not in women. There was also an association between recent illness (flu in the past month and/or recent chest illness) and cough and phlegm in men, and cough in women. Among past chest illnesses measles was, surprisingly, associated with a lower risk of cough and phlegm in men but not in women, whereas other past illness in men and chest illness before the age of 16 in women were associated with usual phlegm. Better socioeconomic status, reflected in education level achieved and job category, was associated with a lower risk of phlegm in men but with an increased risk of shortness of breath in women. Reported past chest illness and chest illness before the age of 16 were both strongly associ- 
Table 4 Mean (SD) anthropometric characteristics and lung function (standardised for height) of study subjects

\begin{tabular}{|c|c|c|c|c|c|c|c|c|c|c|}
\hline & \multicolumn{5}{|l|}{ Men } & \multicolumn{5}{|l|}{ Women } \\
\hline & $\begin{array}{l}20-34 \\
\text { years }\end{array}$ & $\begin{array}{l}35-44 \\
\text { years }\end{array}$ & $\begin{array}{l}45-54 \\
\text { years }\end{array}$ & $\begin{array}{l}55+ \\
\text { years }\end{array}$ & All & $\begin{array}{l}20-34 \\
\text { years }\end{array}$ & $\begin{array}{l}35-44 \\
\text { years }\end{array}$ & $\begin{array}{l}45-54 \\
\text { years }\end{array}$ & $\begin{array}{l}55+ \\
\text { years }\end{array}$ & All \\
\hline $\begin{array}{l}\text { Number } \\
\text { Height }(\mathrm{cm})\end{array}$ & 55 & 58 & 54 & 39 & 206 & 55 & 63 & 63 & 22 & 203 \\
\hline $\begin{array}{l}\text { Standing } \\
\text { Sitting } \\
\text { Weight (kg) }\end{array}$ & $\begin{array}{r}170 \cdot 7 \\
85 \cdot 4 \\
67 \cdot 6\end{array}$ & $\begin{array}{r}168 \cdot 6 \\
85 \cdot 3 \\
69 \cdot 8\end{array}$ & $\begin{array}{r}168 \cdot 6 \\
85 \cdot 2 \\
71 \cdot 6\end{array}$ & $\begin{array}{r}166 \cdot 3 \\
84 \cdot 2 \\
67 \cdot 7\end{array}$ & $\begin{array}{r}168 \cdot 7 \\
85 \cdot 1 \\
69 \cdot 2\end{array}$ & $\begin{array}{r}157 \cdot 0 \\
80.9 \\
64.9\end{array}$ & $\begin{array}{r}157 \cdot 9 \\
82 \cdot 8 \\
74.5\end{array}$ & $\begin{array}{r}158 \cdot 3 \\
82 \cdot 0 \\
73 \cdot 7\end{array}$ & $\begin{array}{r}160 \cdot 1 \\
83 \cdot 7 \\
80 \cdot 6\end{array}$ & $\begin{array}{r}158 \cdot 0 \\
82 \cdot 1 \\
72 \cdot 3\end{array}$ \\
\hline $\begin{array}{l}\text { FVC (1) } \\
\text { Never smoked } \\
\text { Ever smoked }\end{array}$ & $\begin{array}{l}4 \cdot 32 \\
4 \cdot 43\end{array}$ & $\begin{array}{l}4 \cdot 28 \\
4 \cdot 20\end{array}$ & $\begin{array}{l}3 \cdot 89 \\
4 \cdot 19\end{array}$ & $\begin{array}{l}3.63 \\
3.93\end{array}$ & $\begin{array}{l}4.04(0.65) \\
4.22(0.51)^{*}\end{array}$ & $\begin{array}{l}3 \cdot 29 \\
3 \cdot 45\end{array}$ & $\begin{array}{l}3 \cdot 23 \\
3 \cdot 42\end{array}$ & $\begin{array}{l}2 \cdot 89 \\
2 \cdot 74\end{array}$ & $\begin{array}{l}2 \cdot 74 \\
3 \cdot 17\end{array}$ & $\begin{array}{l}3.09(0.45) \\
3.17(0.53)^{*}\end{array}$ \\
\hline $\begin{array}{l}\mathrm{FEV}_{1}(\mathrm{l}) \\
\text { Never smoked } \\
\text { Ever smoked }\end{array}$ & $\begin{array}{l}3.74 \\
3.81\end{array}$ & $\begin{array}{l}3 \cdot 54 \\
3 \cdot 28\end{array}$ & $\begin{array}{l}2 \cdot 98 \\
3 \cdot 14\end{array}$ & $\begin{array}{l}2 \cdot 78 \\
2 \cdot 88\end{array}$ & $\begin{array}{l}3.27(0.68) \\
3.33(0.56)^{*}\end{array}$ & $\begin{array}{l}2 \cdot 70 \\
2 \cdot 91\end{array}$ & $\begin{array}{l}2.59 \\
2.70\end{array}$ & $\begin{array}{l}2.22 \\
1.97\end{array}$ & $\begin{array}{l}2.08 \\
1.90\end{array}$ & $\begin{array}{l}2 \cdot 45(0 \cdot 46) \\
2 \cdot 42(0 \cdot 54)\end{array}$ \\
\hline $\begin{array}{l}\text { FEV }_{1} / \text { FVC } \\
\text { Never smoked } \\
\text { Ever smoked }\end{array}$ & $\begin{array}{l}0 \cdot 86 \\
0.86\end{array}$ & $\begin{array}{l}0.83 \\
0.79\end{array}$ & $\begin{array}{l}0.77 \\
0.75\end{array}$ & $\begin{array}{l}0 \cdot 77 \\
0 \cdot 73\end{array}$ & $\begin{array}{l}0.81(0.08) \\
0.79(0.09)\end{array}$ & $\begin{array}{l}0.82 \\
0.83\end{array}$ & $\begin{array}{l}0 \cdot 80 \\
0 \cdot 79\end{array}$ & $\begin{array}{l}0.76 \\
0.72\end{array}$ & $\begin{array}{l}0.76 \\
0.61\end{array}$ & $\begin{array}{l}0.79(0.08) \\
0.76(0.09)^{*}\end{array}$ \\
\hline $\begin{array}{c}\mathrm{FEF}_{25-75}(1 / \mathrm{s}) \\
\text { Never smoked } \\
\text { Ever smoked }\end{array}$ & $\begin{array}{l}4 \cdot 53 \\
4 \cdot 61\end{array}$ & $\begin{array}{l}4 \cdot 11 \\
3 \cdot 02\end{array}$ & $\begin{array}{l}2 \cdot 86 \\
2 \cdot 63\end{array}$ & $\begin{array}{l}2 \cdot 37 \\
2 \cdot 19\end{array}$ & $\begin{array}{l}3.49(1.5) \\
3.23(1.5)\end{array}$ & $\begin{array}{l}2 \cdot 84 \\
3 \cdot 13\end{array}$ & $\begin{array}{l}2 \cdot 47 \\
2 \cdot 38\end{array}$ & $\begin{array}{l}1.95 \\
1.38\end{array}$ & $\begin{array}{l}1.83 \\
0.88\end{array}$ & $\begin{array}{l}2 \cdot 34(0.96) \\
2 \cdot 09(1.03)^{*}\end{array}$ \\
\hline
\end{tabular}

$\mathrm{FVC}=$ forced vital capacity; $\mathrm{FEV}_{1}=$ forced expiratory volume in one second; $\mathrm{FEF}_{25-75}=$ forced expiratory flow.

* Ever smokers significantly different from never smokers of the same gender $(\mathrm{p} \leq 0.05)$.

ated with wheeze in men and women, and with shortness of breath in women.

Table 4 shows the anthropometric characteristics of the subjects and their spirometric lung functions, standardised for height by gender, age, and smoking status. A secular trend in FVC, $\mathrm{FEV}_{1}$, and $\mathrm{FEF}_{25-75}$ with age is evident, with height standardised values progressively decreasing in the older age groups. In addition, in both men and women higher levels of FVC were recorded in ever smokers than in never smokers; however, these differences were not significant in the multivariate analysis when other determinants of lung function level were taken into account (table 5). In men, although height standardised spirometric flow rates reflecting both large airway status $\left(\mathrm{FEV}_{1} / \mathrm{FVC} \%\right)$ and small airway status $\left(\mathrm{FEF}_{25-75}\right)$ were lower in ever smokers than in never smokers in univariate analyses, only the differences in $\mathrm{FEV}_{1} / \mathrm{FVC} \%$ were significant in the multivariate analyses. In women the findings in relation to smoking were directionally similar, although none of the differences were significant in the multivariate analyses (table 5 ). In addition, all spirometric values were higher in asymptomatic smokers than in never smokers (results not

Table 5 Determinants of lung function expressed as mean (SD) differences from the age standardised average value for the reference category

\begin{tabular}{|c|c|c|c|}
\hline Lung function & Determinant & Men & Women \\
\hline FVC (1) & $\begin{array}{l}\text { Past dusty work } \\
\text { Chest injury } \\
\text { Job category } \\
\text { Education } \\
\quad \text { (grade } 10+v \text { grade } 0-4)\end{array}$ & $\begin{array}{l}\text { NS } \\
\text { NS } \\
+0.27(0.06) \\
+0.24(0.06)\end{array}$ & $\begin{array}{l}+0.15(0.09) \\
-0.33(0.15) \\
+0.15(0.09) \\
\text { NS }\end{array}$ \\
\hline $\mathrm{FEV}_{1}(\mathrm{l})$ & $\begin{array}{l}\text { Past dusty work } \\
\text { Chest illness before } 16\end{array}$ & $\begin{array}{l}\text { NS } \\
\text { NS }\end{array}$ & $\begin{array}{l}+0.21(0.04) \\
-0.04(0.09)\end{array}$ \\
\hline $\mathrm{FEV}_{1} / \mathrm{FVC}(\%)$ & $\begin{array}{l}\text { Smoking } \\
\text { Flu in the last month } \\
\text { Chest illness before } 16\end{array}$ & $\begin{array}{l}-2.8(0.59) \\
\text { NS } \\
\text { NS }\end{array}$ & $\begin{array}{l}\text { NS } \\
-1.9(1.0) \\
-2.2(1.6)\end{array}$ \\
\hline $\mathrm{FEF}_{25-75}(\mathrm{l} / \mathrm{s})$ & $\begin{array}{l}\text { Education } \\
\quad(\text { grade } 10+v \text { grade } 0-4) \\
\quad(\text { grade } 5-9 v \text { grade } 0-4)\end{array}$ & $\begin{array}{l}+0.37(0.20) \\
-0.34(0.14)\end{array}$ & $\begin{array}{l}\text { NS } \\
\text { NS }\end{array}$ \\
\hline
\end{tabular}

$\mathrm{FVC}=$ forced vital capacity; $\mathrm{FEV}_{1}=$ forced expiratory volume in one second; $\mathrm{FEF}_{25-75}=$ forced expiratory flow.

Only significant $(p \leq 0.05)$ differences in average values are shown derived from multiple linear regression analyses containing all the potential determinants examined (see text) for subjects exhibiting compared with those not exhibiting the determinant listed. For instance, in women mean FVC for those reporting past dusty exposure was on average 0.151 higher than those not reporting such exposure after taking into account all other determinants. shown), although the differences were only significant for FVC $(p<0 \cdot 05)$.

Other findings in the multivariate analysis (table 5) deserve comment. In women past dusty work was also associated with higher levels of FVC and FEV, consistent with a "healthy" worker effect. Job category (skilled/ professional $v$ not) was also associated with higher levels of FVC in men and women, whereas the relations of education level to $\mathrm{FEF}_{25-75}$ were inconsistent in men, and nonsignificant in women. In women, but not in men, past chest injury was associated with a significant reduction in FVC, while chest illness before the age of 16 was associated with significant reductions in $\mathrm{FEV}_{1}$ and $\mathrm{FEV}_{1}$ / FVC\%, and flu in the last month with a significant reduction in $\mathrm{FEV}_{1} / \mathrm{FVC} \%$.

Regression equations for $\mathrm{FVC}$ and $\mathrm{FEV}_{1}$ derived from the data collected in the present study, based on age (in years) and standing or sitting height (in $\mathrm{cm}$ ), are as follows:

Men:

$\mathrm{FVC}=0.053$ (standing height) -0.021 (age) $-3.85\left(R^{2}=0.427\right)$;

FVC $=0.083$ (sitting height $)-0.025$

$-1.83\left(R^{2}=0.330\right)$

$\mathrm{FEV}_{1}=0.035$ (standing height) -0.036 (age)

$-1.15\left(R^{2}=0.507\right)$;

$\mathrm{FEV}_{1}=0.050$ (sitting height) -0.039 (age)

$+0.72\left(R^{2}=0.449\right)$;

Women:

$\mathrm{FVC}=0.045$ (standing height) -0.023 (age)

$-3.04\left(R^{2}=0.370\right)$;

$\mathrm{FVC}=0.064$ (sitting height) -0.024 (age)

$-1.20\left(R^{2}=0.254\right)$

$\mathrm{FEV}_{1}=0.034$ (standing height) -0.028 (age)

$-1.87\left(R^{2}=0.388\right)$

$\mathrm{FEV}_{1}=0.051$ (sitting height) -0.029 (age)

$-0.55\left(R^{2}=0.319\right)$.

Both in men and in women age and standing height accounted for a greater proportion of variation than age and sitting height, while equations including age, standing height, sitting height, and sitting/standing height ratio (not shown) only marginally increased the $R^{2}$ for FVC (to 0.432 in men and to 0.375 in women), and for $\mathrm{FEV}_{1}$ (to 0.517 in men and to 0.392 in women). 
Table 6 Forced vital capacity (FVC) in selected studies of black men in southern Africa

\begin{tabular}{|c|c|c|c|c|c|c|c|c|}
\hline \multirow[t]{3}{*}{ Reference } & \multirow{3}{*}{$\begin{array}{l}\text { Population, city/area, } \\
\text { (country) }\end{array}$} & \multirow{3}{*}{$\begin{array}{l}\text { Mean (SD } \\
\text { or range) age } \\
\text { (years) }\end{array}$} & \multirow{3}{*}{$\begin{array}{l}\text { Mean }(S D \\
\text { or range) } \\
\text { height }(\mathrm{cm})\end{array}$} & \multicolumn{3}{|c|}{ Prediction equation } & \multirow{3}{*}{$\begin{array}{l}F V C \\
\text { predicted } \\
\text { for age } 35 \text {, } \\
\text { ht } 170 \mathrm{~cm}\end{array}$} & \multirow[t]{3}{*}{ Selection criteria for subjects } \\
\hline & & & & \multicolumn{2}{|c|}{ Regression coefficients } & \multirow{2}{*}{$\begin{array}{l}\text { Intercept } \\
\left(R^{2}\right)\end{array}$} & & \\
\hline & & & & Height & Age & & & \\
\hline \multirow{3}{*}{$\begin{array}{l}\text { Johanssen } \\
(1968)^{6} \\
\text { Cookson } \\
(1976)^{8} \\
\text { Yach } \\
(1984)^{11}\end{array}$} & \multirow{3}{*}{$\begin{array}{l}120 \text { hospital workers, } \\
\text { Pretoria (S Africa) } \\
141 \text { urban workers, Harare } \\
\text { (Zimbabwe) } \\
153 \text { package plant workers, } \\
\text { Cape Town (S Africa) }\end{array}$} & $34 \cdot 1(9 \cdot 1)$ & $167 \cdot 0(6 \cdot 4)$ & +0.038 & - & $-2 \cdot 84(0 \cdot 22)$ & $3.98^{*}$ & Included smokers \\
\hline & & $43 \cdot 6(15 \cdot 1)$ & $171 \cdot 3(7 \cdot 1)$ & +0.039 & -0.017 & $-2 \cdot 32(0 \cdot 30)$ & $3 \cdot 72$ & \multirow{2}{*}{$\begin{array}{l}\text { Included smokers, exclusions only } \\
\text { for abnormal radiography } \\
\text { Included smokers }(68 \%) ; 86 \% \\
\text { subjects were Xhosa, } 14 \% \\
\text { coloured }\end{array}$} \\
\hline & & $36 \cdot 1(13 \cdot 7)$ & $171.9(7 \cdot 2)$ & +0.047 & -0.027 & $-3.27(0 \cdot 38)$ & $3 \cdot 78$ & \\
\hline $\begin{array}{l}\text { Myers } \\
(1985)^{10}\end{array}$ & $\begin{array}{l}203 \text { stevedores, Port } \\
\text { Elizabeth (S Africa) } \dagger\end{array}$ & 45 & Not reported & +0.045 & -0.033 & $-2.44(0.42)$ & 4.05 & $\begin{array}{l}\text { Included smokers }(76 \%) \text { and men } \\
\text { with radiographic changes } 1 / 0 \text { or } \\
\text { more }(30 \%)\end{array}$ \\
\hline $\begin{array}{l}\text { Fox } \\
(1988)^{12}\end{array}$ & $\begin{array}{l}300 \text { mine and smelter } \\
\text { workers, Selebi Phikwe } \\
\text { (Botswana) }\end{array}$ & $34 \cdot 2(20-60)$ & 172.9 & +0.057 & $-0 \cdot 008$ & $-5 \cdot 23(0 \cdot 32)$ & $4 \cdot 11 \S$ & $\begin{array}{l}\text { Included smokers without } \\
\text { symptoms }(26 \%)\end{array}$ \\
\hline \multirow{5}{*}{$\begin{array}{l}\text { Coetzee } \\
(1989)^{19} \\
\text { Hessel } \\
(1989)^{18} \\
\text { White } \\
(1989)^{14} \\
\text { Goldin }^{19} \\
(1989)^{17} \\
\text { This study } \\
(1990)\end{array}$} & \multirow{5}{*}{$\begin{array}{l}518 \text { workers in an asbestos } \\
\text { cement factory (S Africa) } \\
646 \text { rural mining and } \\
\text { industrial workers (S Africa) } \\
109 \text { textile workers, } \\
\text { Cape/Natal (S Africa) } \\
106 \text { bank workers, } \\
\text { Johannesburg (S Africa) } \\
206 \text { university workers, } \\
\text { Johannesburg (S Africa) }\end{array}$} & $33 \cdot 1(8 \cdot 8)$ & $169 \cdot 4(6 \cdot 3)$ & +0.055 & -0.016 & $-4.50(0.37)$ & $4 \cdot 29 \S$ & \multirow{2}{*}{$\begin{array}{l}\text { All subjects clinically normal; } \\
\text { included smokers }(60 \%) \\
\text { Included smokers; not exposed }\end{array}$} \\
\hline & & $41 \cdot 6(7 \cdot 9)$ & $171 \cdot 4(6 \cdot 2)$ & +0.052 & -0.021 & $-3.86(0.36)$ & $4 \cdot 25 \S$ & \\
\hline & & $36 \cdot 1(8 \cdot 3)$ & $167 \cdot 3(6 \cdot 9)$ & +0.065 & -0.022 & $-6 \cdot 16(0 \cdot 64)$ & $4 \cdot 12 \S$ & \multirow{3}{*}{$\begin{array}{l}\text { Non-smokers; not exposed to } \\
\text { cotton dust } \\
\text { Healthy non-smokers without } \\
\text { symptoms } \\
\text { All subjects }(n=206) \\
\text { Never smokers }(n=172) \\
\text { Never smokers without symptoms } \\
(n=49)\end{array}$} \\
\hline & & Approx 41 & Approx 170 & +0.048 & -0.024 & $-3.08(0.33)$ & $4 \cdot 24 \S$ & \\
\hline & & $42.0(10.5)$ & $168 \cdot 7(6 \cdot 5)$ & $\begin{array}{l}+0.053 \\
+0.055 \\
+0.053\end{array}$ & $\begin{array}{l}-0.021 \\
-0.024 \\
-0.029\end{array}$ & $\begin{array}{l}-3.85(0.43) \\
-4.25(0.42) \\
-3.66(0.51)\end{array}$ & $\begin{array}{l}4 \cdot 42 \S \\
4 \cdot 26 \S \\
4 \cdot 33 \S\end{array}$ & \\
\hline
\end{tabular}

* Results were reported at ATPS; corrected to BTS by a factor of $10 \%$.

$\dagger$ Handle asbestos cargoes.

$\S$ Measured using a Vitalograph.

\section{Discussion}

SYMPTOM PREVALENCE AND DETERMINANTS IN THE PRESENT STUDY

This study of the respiratory health status of a workforce comprising men and women not currently exposed to dust or fumes at work has shown high prevalences of bronchitic symptoms (related principally to current smoking and past exposures to inhaled pollutants, and to past respiratory illness), of wheezing (also related to past respiratory illness), and of shortness of breath in women (probably related to their high body mass index). While these associations are coherent and many have been reported in other more homogeneous populations, consideration of the potential sources of bias in the present findings is in order, particularly since all the explanatory variables examined were self reported. Such information is inevitably subject to recall bias which could not be evaluated. In addition, administration of the questionnaire in this study was not standard, since the interviewers translated freely from a written English version to the interviewee's language of choice. However, this method has been previously tested in a similar Johannesburg workforce and yielded a level of reproducibility, for instance, for sputum questions comparable to that obtained by standard methods in more homogeneous populations in the UK and the USA. ${ }^{5}$ In addition, psychological perceptions influence the reporting of respiratory symptoms $^{36}$ and may have affected internal validity in the present study. For instance, in women childhood respiratory illness before the age of 16 was significantly associated with "usual phlegm" but not "usual cough" (table 3), suggesting that in this population coughing to bring up phlegm is perceived and reported as phlegm, and not otherwise reported. This issue is pertinent to the use of any internationally acclaimed questionnaires among populations whose perception of symptoms such as cough and phlegm production may not be the same as that of populations among whom the questionnaire was originally validated.

\section{COMPARISON OF SYMPTOM PREVALENCE WITH} PUBLISHED DATA

In theory generalisability of the present findings to other urban workforces, even in South Africa, is likely to be limited since selection factors, recruitment policies, turnover rates, and perceptions of the employer by employees and vice versa are all likely to affect study findings. Of interest, therefore, is the fact that using the same questionnaire and method of administration the prevalence of usual phlegm in men in the present study was $19.3 \%$, comparable to $19-23 \%$ reported in a study in another largely male Johannesburg workforce not exposed to dust or fumes at work, ${ }^{5}$ but less than the $43.4 \%$ reported by men working in a Johannesburg grain mill, ${ }^{20}$ an exposure known to be associated with industrial bronchitis. Likewise, generalisability of this study to other populations of different cultural and language groups is likely to be even more limited. Nevertheless, some of the present findings are in agreement with the results reported in the Tucson, Arizona, study of the natural history of chronic obstructive pulmonary disease in which an association was also shown between wheezing symptoms in adulthood and chest illness before the age of 16 , defined by the questionnaire ${ }^{37}$ as in the present study.

\section{LUNG FUNCTIONS AND DETERMINANTS IN THE} PRESENT STUDY

Smoking is recognised as a major cause of reduced lung function. ${ }^{39}$ Unusual aspects of the relation of lung function level to smoking status in the present study which deserve comment are: (1) the only significant negative effect of smoking was in men, and only for the 
Table 7 Forced vital capacity (FVC) in selected studies of black women in southern Africa

\begin{tabular}{|c|c|c|c|c|c|c|c|c|}
\hline \multirow[t]{3}{*}{ Reference } & \multirow{3}{*}{$\begin{array}{l}\text { Population, city/area, } \\
\text { (country) }\end{array}$} & \multirow{3}{*}{$\begin{array}{l}\text { Mean (SD } \\
\text { or range) age } \\
\text { (years) }\end{array}$} & \multirow{3}{*}{$\begin{array}{l}\text { Mean }(S D \\
\text { or range) } \\
\text { height }(\mathrm{cm})\end{array}$} & \multicolumn{3}{|c|}{ Prediction equation } & \multirow{3}{*}{$\begin{array}{l}F V C \\
\text { predicted } \\
\text { for age } 35 \text {, } \\
\text { ht } 160 \mathrm{~cm}\end{array}$} & \multirow[t]{3}{*}{ Selection criteria for subjects } \\
\hline & & & & \multicolumn{2}{|c|}{ Regression coefficients } & \multirow{2}{*}{$\begin{array}{l}\text { Intercept } \\
\left(R^{2}\right)\end{array}$} & & \\
\hline & & & & Height & Age & & & \\
\hline \multirow{4}{*}{$\begin{array}{l}\text { Johanssen } \\
(1968)^{6} \\
\text { Cookson } \\
(1976)^{8} \\
\text { White } \\
(1989)^{14} \\
\text { This study } \\
(1990)\end{array}$} & \multirow{4}{*}{$\begin{array}{l}100 \text { hospital workers, } \\
\text { Pretoria (S Africa) } \\
102 \text { urban workers, Harare } \\
\text { (Zimbabwe) } \\
119 \text { textile workers, } \\
\text { Cape/Natal (S Africa) } \\
203 \text { university workers, } \\
\text { Johannesburg (S Africa) }\end{array}$} & $34 \cdot 6(8 \cdot 7)$ & $156 \cdot 6(6 \cdot 6)$ & +0.023 & -0.014 & $-0.66(0.32)$ & $2 \cdot 79$ & Mainly nurses; very few smokers \\
\hline & & $36 \cdot 7(11 \cdot 6)$ & $160 \cdot 7(5 \cdot 9)$ & +0.030 & -0.019 & $-1 \cdot 24(0 \cdot 38)$ & $2 \cdot 89$ & \multirow{3}{*}{$\begin{array}{l}\text { Includes smokers; exclusions only } \\
\text { for abnormal radiography } \\
\text { Non-smokers; not exposed to } \\
\text { cotton dust } \\
\text { All subjects }(n=203) \\
\text { Never smokers }(n=174) \\
\text { Never smokers without symptoms } \\
(n=94)\end{array}$} \\
\hline & & $29.5(7.5)$ & $160 \cdot 1(6 \cdot 7)$ & +0.037 & -0.027 & $-1.54(0.31)^{*}$ & $2 \cdot 79$ & \\
\hline & & $41 \cdot 0(9 \cdot 8)$ & $158 \cdot 0(5 \cdot 5)$ & $\begin{array}{l}+0.045 \\
+0.042 \\
+0.044\end{array}$ & $\begin{array}{l}-0.023 \\
-0.021 \\
-0.023\end{array}$ & $\begin{array}{l}-3.04(3.7) \\
-2.71(0.34) \\
-2.87(0.33)\end{array}$ & $\begin{array}{l}3 \cdot 35 \\
3 \cdot 27 \\
3 \cdot 36\end{array}$ & \\
\hline
\end{tabular}

* Prediction formula includes a coefficient for weight in $\mathrm{kg}(-0.008)$.

Number of subjects in the regression analysis.

$\mathrm{FEV}_{1} / \mathrm{FVC} \%$ ratio (table 5); (2) FVC and $\mathrm{FEV}_{1}$ levels were higher in ever smokers than in never smokers. The absence of demonstrable negative effects on the level of spirometric lung functions may be related both to the low intensity of smoking in the present study population and to the "healthy" smoker effect. This term has been used to draw attention to the fact that there appears to be selective uptake of the smoking habit by individuals with higher levels of lung function (for which there is no obvious biological explanation), and lower levels of airway responsiveness to inhaled materials (for which there are biologically plausible explanations)..$^{4041}$ Similar observations have been reported elsewhere in longitudinal ${ }^{42}$ and cross sectional studies, ${ }^{43}$ including studies on black subjects resident elsewhere in Africa. ${ }^{44}$ Also, given that $\mathrm{FEV}_{1}$ is a function of FVC, a "healthy" smoker effect on $\mathrm{FEV}_{1}$ is likely to be detectable in individuals at the time of taking up the habit or soon after - that is, before the negative effects of tobacco exposure have become evident. ${ }^{3941}$ In the present results it is therefore somewhat surprising that differences between ever and never smokers consistent with the "healthy" smoker effect on $\mathrm{FEV}_{1}$ were demonstrable, even in men in the 45-54 and 55-64 age subgroups. The explanation may also lie in the low intensity of the smoking habit in the study participants.

\section{COMPARISON OF LUNG FUNCTIONS WITH} PUBLISHED DATA

One of the goals of the study was to contribute information pertinent to establishing reference values for use in the clinical interpretation of lung function in black South African men and women. A strength of the data as a source of reference values derives from the fact that both men and women were studied by the same team using the same methodology. Pertinent also are comparisons with other studies in southern African subjects. These were carried out by calculating the predicted values for FVC for a 35 year old man $170 \mathrm{~cm}$ in height and a 35 year old woman $165 \mathrm{~cm}$ in height, using the published regression equations for each study, and comparing these with the predicted values derived from the equations based on the present study. Of note in the data for men, shown chronologically in table 6 , is a secular trend with FVC values increasing over the past decades. Note also that values in the present study (including smokers) are higher than those derived from other studies of nonsmoking black men ${ }^{14}$ and of non-smoking black men without symptoms ${ }^{17}$ resident in southern Africa. Values for the present study are also higher than those derived from the only other studies conducted in workforces without known harmful industrial exposure, namely hospital workers in Pretoria ${ }^{6}$ and package plant workers in Cape Town, ${ }^{11}$ and higher than values obtained in all other studies using the same instrumentation - that is, the Vitalograph. ${ }^{610220}$ Only three reports of spirometric values in black women from southern Africa were found, ${ }^{6814}$ and these also yield lower values than those found in the present study (table 7).

Factors which may have contributed to the high values for the spirometric parameters obtained in the present study include the use of standing posture for testing, and the absence of known harmful industrial exposure in the workforce studied. In addition, methodology for measuring spirometric values has evolved over the years. A more pertinent factor may be the changing socioeconomic status of the blacks in southern Africa. For instance, in the present study socioeconomic indicators such as education level achieved and job position were associated with higher FVC levels in men, even though the number of subjects in the upper socioeconomic group was small. Negative effects of urbanisation such as environmental and occupational exposures may therefore have been offset by improved nutrition and access to health care through medical aid plans, all of which may be pertinent in an employed population such as the one studied here.

This paper is based on material accepted for the degree of MSc (Med) which was awarded by the University of the Witwatersrand to K Mokoetle in 1990. The authors wish to acknowledge the enthusiastic cooperation of the study participants, the Black University Workers' Association (BUWA), and the University of the Witwatersrand. The study was carried out using the facilities of the Epidemiology Unit, National Centre for Occupational Health, Johannesburg, and received strong academic and moral support from Professor J C A Davies, Drs Anemic Zwi and Malcolm Steinberg Zwi and Malcolm Steinberg, Linda Malekela, and the staff of the Epidemiology Unit, as well as the library staff at the National Centre for Occupational Health. Financial suppor from the Medical Research Council of South Africa, the Richard Ward Foundation, and the Levenberg Bequest of the University of Witwatersrand is also gratefully acknowledged. Dr Becklake was supported by a Career Investigator Award of the Medical Research Council of Canada. 
1 Ferris BG. Epidemiology standardization project. Am Rev Respir Dis 1978;118(Suppl):1-118

2 American Thoracic Society. Standardization of spirometry: 1987 update. Am Rev Respir Dis 1987;136:1285-98.

3 Murray JF. Chronic airway disease: distribution and determinants, prevention and control. Chest 1989;96:301S

4 Chaulet P. Asthma and chronic bronchitis in Africa. Evidence from epidemiological studies. Chest 1989;96(Suppl 3):334s-9s.

5 Becklake MR, Freeman S, Goldsmith C, Hessel PA, Mkhwelo $\mathrm{R}$, Mokoetle $\mathrm{K}$, et al. Respiratory question-
naires in occupational studies: their use in multilingual naires in occupational studies: their use in multilingual
workforces on the Witwatersrand. Int $\mathcal{f}$ Epidemiol workforces on

6 Johannsen ZM, Erasmus LD. Clinical spirometry in normal Bantu. Am Rev Respir Dis 1968;97:585-97.

7 Van de Wal BW, Erasmus LD, Hechter R. Stem and standing heights in Bantu and white South Africans: their significance in relation to pulmonary function values. $S$ Afr Med 7 1971;45:568-70.

8 Cookson JB, Blake GTW, Franisi C. Normal values for ventilatory function in Rhodesian Africans. $B r \mathcal{F} D$ is Chest 1976;70:70-111.

9 Sluis-Cremer GK, Harrison WO, Pearson RCT. Respiratory symptoms and lung function in black and white mining and non-mining industrial workers in South Africa. $S$ Afr Med $\mathcal{F}$ 1981;59:672-5.

10 Myers JE, Garisch D, Myers HS, Connell JE, Rwexu RD. A respiratory epidemiologic study of stevedores intermittently exposed to asbestos in a South African port. $A m \mathcal{F}$ Ind Med 1985;7:273-83.

11 Yach D, Myers J, Bradshaw D, Benatar SR. A respiratory epidemiologic survey of grain mill workers in Cape
Town, South Africa. Am Rev Respir Dis 1985;131:505-10.

12 Fox DH. Spirometry in healthy adult males in Botswana. Central Afr f Med 1988;34:106-14.

13 Rees D. Spirometry: test acceptability and reproducibility in a South African workplace. S Afr $\mathcal{J}$ Epidemiol Infect 1988;3:5-8.

14 White N. Byssinosis in South Africa. S Afr Med $f$ 1989;75:435-42.

15 Myers J, Lewis P, Hofmeyr W. Respiratory health of brick workers in Cape Town, South Africa. Scand $\mathcal{f}$ Work workers in Cape Town, Sou
Environ Health 1989;15:180-7.

16 De Kock MA, Swiggers WRS, Kotze TJ van W, Joubert G. Cross-sectional study of uranium mine workers to develop predictive equations for lung functions with reference to chronic obstructive pulmonary disease. $S$ Afr Med f 1988;73(Suppl): $1-20$.

17 Goldin JG. Spirometric and gas transfer measurements among normal adult South African men; an investigation into anthropometric, socioeconomic, racial and environmental factors influencing lung function. PhD Thesis, University of Cape Town, 1989.

18 Hessel PA, Sluis-Cremer GK. Prediction equation for lung function in black industrial workers at Phalaborwa Mining Company. S Afr Med F 1989;76:548-9.

19 Coetzee AM, Becker PJ. Lung function screening in industry. $S$ Afr Med $\mathcal{F}$ 1989;76:550-3.

20 Fonn S, Groeneveld $H$, de Beer M, Becklake MR. An environmental and respiratory health survey of a grain in the Germiston area, South Africa. Am $\mathcal{F}$ Ind $\mathrm{Med}$ 1993;24:401-11.

21 Becklake MR. Concepts of normality applied to the measurement of lung function. $\mathrm{Am} \mathcal{F} \mathrm{Med}$ 1986;80:115864.

22 Miller A, Thorton JC. The interpretation of spirometric measurements in epidemiological surveys. Environ Res 1980;23:444-68.

23 American Thoracic Society. Lung function testing: selec- tion of reference values and interpretative strategies. $\mathrm{Am}$ Rev Respir Dis 1991;144:1202-18.

24 Abramowitz S, Leiner GC, Lewis WA, Small MJ. Vital capacity in the negro. Am Rev Respir Dis 1965;92:287-92.

25 Damon A. Negro-White differences in pulmonary function (vital capacity, time vital capacity and expiratory flow rate). Hum Biol 1966;38:380-93.

26 Miller GJ, Ashcroft MT, Swan AV, Beadnell HMGS. Ethnic variation in forced expiratory volume and forced vital capacity of African and Indian adults in Guyana. Am vev Respir Dis 1970;102:979-81.

27 Mustafa KY. Spirometric lung function tests in normal men of African ethnic origin. Am Rev Respir Dis 1977;116:209-13.

28 Schoenberg JB, Beck GJ, Bouhuys A. Growth and decay of pulmonary function in healthy blacks and whites. Respir Physiol 1978;33:367-93.

29 Morris JF, Koski A, Johnson LC. Spirometric standards for healthy non-smoking adults. Am Rev Respir Dis 1971;103:57-67.

30 Knudson RJ, Slatin RC, Lebowitz MD, Burrows B. The maximal expiratory flow volume curve and normal standmaximal expiratory flow volume curve and normal standards, variability and

31 Crapo RO, Morris AH, Gardner RM. Reference spirometric values using techniques and equipment that meet ATS recommendations. Am Rev Respir Dis 1981;123:659-64.

32 Burrows B, Cline MG, Knudson RJ, Taussig LM, Lebowitz MD. A descriptive analysis of the growth and decline of FVC and FEV . Chest 1983;83:717-24.

33 Myers J. Differential ethnic standards for lung function or one standard for all? S Afr Med f 1984;65:768-72.

34 Davies JCA, Becklake MR. Reference values for lung function: more to be done. S Afr Med $\mathcal{f} 1984 ; 66: 830$.

35 Schlemmer L, Stopforth P. A guide to the coding of occupations in South Africa. Fact Paper, No. 4, University of Natal, 1979 .

36 Dales RE, Spitzer WO, Schechter MT, Suissa S. The influence of psychological status on respiratory symptom reporting. Am Rev Respir Dis 1989;139:1459-63.

37 Burrows B, Knudson RJ, Lebowitz MD. The relationship of childhood respiratory illness to adult obstructive airway disease. Am Rev Respir Dis 1977;115:751-60.

38 Lalloo U, Becklake MR, Goldsmith C. Effects of standing versus sitting position on spirometric indices in healthy subjects. Respiration 1991;58:122-5.

39 Surgeons General's Advisory Committee on Smoking and Health. Public Health Service Publication 1103. Washington DC: US Government Printing Office, 1964:25693.

40 Weiss ST, O'Connor GT, Sparrow D. The role of allergy and airway responsiveness in the natural history of chronic airflow obstruction (CAO). In: Weiss ST, Sparrow D, eds. Airway responsiveness and atopy in the development of chronic lung disease. New York: Raven Press, 1989:181240 .

41 Becklake MR, Lalloo U. The "healthy" smoker: a phenomenon of health selection? Respiration 1990;57:137-44

42 Tashkin DB, Clark VA, Coulson AH, Bourne LB, Simmons $M$, Reems C, et al. Comparison of lung function in young non smokers and smokers before and after initiation of the smoking habit. Am Rev Respir Dis 1983;128:12-16.

43 Leech JA, Ghezzo H, Stevens D, Becklake MR. Respiratory pressures and lung function in young adults. Am Rev Respir Dis 1983;128:17-23.

44 Oleru UG. Pulmonary function of control and industrially exposed Nigerians in asbestos, textile, and toluene diisocyanate foam factories. Environ Res 1980;23:137-48. 